\title{
Pineapple Juice for Uterine Fundal Height Reduction in Postpartum Mothers
}

\author{
Jesica Mulyadi, Mariati, Lusi andriani, Rachmawati
}

Department of Health Poltekkes Bengkulu, Ministry of Health

\section{ABSTRACT}

Background: Uterine subinvolution occurs because the uterus cannot contract properly, causing bleeding, leading to death. Pineapple fruit is one of the herbal plants that can prevent uterine subinvolution and accelerate uterine involution. This study aimed to determine pineapple's effect on the reduction of uterine fundal height in postpartum mothers in Bengkulu City.

Subjects and Method: This was a quasiexperiment. This study was conducted in Bengkulu City, Bengkulu, and using maternal postpartum injected oxytocin in the management stage III with one intervention group, namely the given juice pineapple. The sample used as many as 32 mothers postpartum in Bengkulu were taken by purposive sampling, by predetermined criteria. The dependent variable was uterine fundal height. The independent variables were pineapples juice, age, parity, early mobilization, and early initiation of breastfeeding. Data collection was carried out by the means of the direct interview using a questionnaire and observation sheet. The data were analyzed using independent t-test.

Results: The bivariate analysis test results using the independent t-test showed that the group that consumed pineapples experienced a decrease in uterine fundal height for three days more than the control group. Pineapples juice (Mean $=2.55 ; \mathrm{SD}=1.66)$, without pineapples juice (Mean $=8.39 ; \mathrm{SD}=1.48 ; \mathrm{p}<0.001)$. Age for interventions group, (Mean= 33.19; $\mathrm{SD}=$ 7.57) and control group (Mean= 27.56; $\mathrm{SD}=$ 8.45; $\mathrm{p}=0.057)$. Parity for interventions group, (Mean $=2.38 ; \mathrm{SD}=1.45)$ and control group, $(\mathrm{Mean}=2.12 ; \mathrm{SD}=1.31), \mathrm{p}=0.613$. Early mobilization for interventions group, $($ Mean $=0.84$; $\mathrm{SD}=0.37)$ and control group, $(\mathrm{Mean}=1.26$; $\mathrm{SD}=0.58), \mathrm{p}=0.022$. Early initiation of breastfeeding for interventions group, $($ Mean $=16.44$; $\mathrm{SD}=6.64)$ and control group, $($ Mean $=16.38$; $\mathrm{SD}=5.69), \mathrm{p}=0.978$.

Conclusion: Pineapple juice and early mobilization affect lowering a uterine fundal height in mothers postpartum three days and can help speed up uterine involution in postpartum mother in Bengkulu City, Bengkulu.

Keywords: pineapple juice, uterine fundal height, postpartum

\section{Correspondence:}

Jesica Mulyadi. Department of Midwifery, Health Polytechnics, Ministry of Health Bengkulu. Indri Giri Street Number 03, Bengkulu, Bengkulu Province. Email: Jesicamulyadi25@gmail.com.

\section{Cite this as:}

Mulyadi J, Mariati, Lusi andriani L, Rachmawati (2021). Pineapple Juice for Postpartum Mothers: Reduction in Uterine Fundal Height in Bengkulu, Indonesia. J Matern Child Health. 06(04): 467-474. https://doi.org/10.26911/thejmch.2021.06.04.08.

cc (i) (2) Journal of Maternal and Child Health is licensed under a Creative Commons Attribution-NonCommercial-ShareAlike 4.o International License.

\section{BACKGROUND}

Maternal mortality and morbidity are serious health problems that often occur in developing countries. Indonesia has the highest maternal mortality rate compared to other ASEAN countries, which is 359 per
100 thousand live births (BPS et al., 2013). According to Prawirohardjo (2008), 50\% of maternal deaths in the postpartum period within the first 24 hours mostly caused due to bleeding postpartum (Bateman et al., 2010). Postpartum hemorrhage was defined 
as blood loss $>500 \mathrm{ml}$ after vaginal delivery and $>1000 \mathrm{ml}$ after cesarean section (Moedjiarto, 2011; Bateman et al., 2010). Postpartum hemorrhage occurs in the first 24 hours and after the early 24 hours to less than weeks after delivery. According to Moedjiarto (2011), postpartum hemorrhage caused by uterine atony (50-60)\%, retained placenta (23-24)\%, birth canal laceration (5$6 \%$ ), infections, and disorders of freezing $d$ direction (0.4- 0.6)\%. Placental infection and retention are the leading causes of cases of uterine subinvolution (Moedjiarto, 2011). The process of involution of the uterus that does not go well is called uterine subinvolution, which can cause bleeding (5 - 15\%), blood circulation is not smooth, hypovolemic shock (20\%), and even lead to death (50\%) (Ambarwati et al., 2010; Prawirohardjo, 2008). One way that can help the process of uterine involution is by using pineapples (Ho et al., 2011).

Pineapple is a type of fruit that contains the enzyme bromelain. The bromelain enzyme found in pineapple can stimulate prostaglandins' secretion so that the uterus can contract adequately (Katno et al., 2010; Pavan et al., 2012). It is in line with Harianja et al. (2017) using ripe pineapple fruit as much as 250 grams of juice, to $200 c c$ with an intensity of giving once a day for seven days; the result was a decrease in the average height of the uterine fundus by 8,15 $\mathrm{cm}$ for seven days. The research supports this (Apsari et al., 2016) using female mice, then given the extract of young and old pineapple fruit, the results showed that pineapple extract with a concentration of $0.6 \%$ could increase uterine contractions by 0.944 times faster than aged pineapple extract. Apart from pineapple fruit, several factors can accelerate the process of uterine involution, namely age, parity, early initiation of breastfeeding, and early mobilization (Ambarwati et al., 2010).
The survey was conducted in September 2018 in 5 subdistrict of Bengkulu's city by interviewing the mother postpartum about lochia expenditure on 15 respondents. Of the 15 respondents, it was found that nine respondents still had serious like on the 15th - 18th day postpartum and six people with lochia alba expenditure on the $13^{-15^{\text {th }}}$ day postpartum. They consume various kinds of drinks that can help the process of uterine involution, one of which is black pudding boiled water. Although black pudding cooked water can help the process of uterine involution, based on a survey conducted, many postpartum mothers experience symptoms of anemia due to consuming this boiled water. Based on the initial study undertaken, it is necessary to research the effect of consuming pineapple on uterine involution in independent midwife practice Bengkulu City. This study aimed to determine the effect of pineapple on a decrease in uterine fundal height in postpartum mothers in Bengkulu City in 2018.

\section{SUBJECTS AND METHOD}

\section{Study Design}

This was a quasi-experiment. This study used two groups of postpartum mothers injected with oxytocin during stage III, and there was one group that would intervene by giving pineapple juice. This study was carried out in Bengkulu, Indonesia.

\section{Population and Sample}

The study population was postpartum mothers in Bengkulu. The sample of the study was 32 mothers postpartum were taken by purposive sampling and they are will be divided into two groups, 16 mothers postpartum in the intervention group and 16 mothers postpartum in the control group. The criteria were contained in subdistricts Ratu Agung, Singaran Pati, and Selebar do not suffer from or have a history of gastritis, 
had an age range of 17 - 45 years, not allergic to pineapple, postpartum mothers 6 hours, and parity of $1-5$.

\section{Study Variables}

The dependent variables were uterine involution. The independent variable was Pineapple. The confounding variables age, early mobilization, early initiation of breastfeeding and parity.

\section{Operational Definition of Variables} Uterine Involution has defined the process of returning the uterus to its prepregnancy state utilizing the uterus contracting resulting in a decrease in height fundal uterine. The measuring instrument uses an observation sheet. The data scale was a category.

Pineapple was defined as juice obtained from 450 grams of pineapple by blending pineapple using a juicer and only the juice is taken. Drink pineapple juice 2 hours after lunch as much as $1 \times 1$. This juice gives to the intervention group. The measuring instrument uses an observation sheet.

Age was defined age is the length of time a person lives. The measuring instrument uses an observation sheet. The data scale was continuous

Early mobilization was defined early Mobilization is the earliest possible movement made by a mother. The measuring instrument uses an observation sheet. The data scale was continuous.

Parity was defined as parity is the number of deliveries that a person experiences. The measuring instrument uses an observation sheet. The data scale was continuous.
Early initiation of breastfeeding was defined early initiation of breastfeeding as the length of the process the baby feeds on the mother immediately after birth. The measuring instrument uses an observation sheet. The data scale was continuous.

\section{Study Instruments}

The researcher conducted direct interviews at 6 hours postpartum mothers using questionnaires and observation using the observation sheet. Measuring the height of the uterine fundus using a pelvic meter, then the measurement results are measured again using a meter so that the results obtained are more accurate.

\section{Data Analysis}

The data were analyzed using t-test independent with a significance level of $5 \%$ to determine the impact of those factors on uterine involution for postpartum mothers.

\section{Research Ethics}

The research ethics was obtained from Health Polytechnics, Ministry of Health Bengkulu with Number: No. DM. 01.04/ 87/3/XII/2018. This study used a questionnaire containing an approval sheet, respondent characteristics, and a respondent's observation sheet.

\section{RESULTS}

\section{Subjects Characteristics}

Table 1 describes the respondents' characteristics consisting of age, parity, research group, early mobilization, and early initiation of breastfeeding. In this research, the variable is divided into two groups: the intervention and control groups.

\section{Table 1. Sample characteristics (Categorical data)}

\begin{tabular}{lcccc}
\hline \multicolumn{1}{c}{ Characteristics } & \multicolumn{2}{c}{ Intervention } & \multicolumn{2}{c}{ Control } \\
\cline { 2 - 5 } & Frequency & Percentage & Frequency & Percentage \\
\hline Age & 7 & $44 \%$ & 8 & $50 \%$ \\
Women of reproductive age & 9 & $56 \%$ & 8 & $50 \%$ \\
Non women of reproductive age & & & & \\
Parit & 6 & $37 \%$ & 7 & $44 \%$ \\
Primiparous & 10 & $63 \%$ & 9 & $56 \%$ \\
Multiparous & & & & \\
\hline
\end{tabular}


Mulyadi et al./ Pineapple Juice for Uterine Fundal Height Reduction

Based on table 1, it was explained that in the age variable, the intervention group has a higher reproductive unhealthy age ( $<20$ years, >35 years) compared to the control group, namely $56 \%$. Whereas in the control group, respondents with healthy reproductive age and unhealthy reproductive age were 50\%. The parity variables explained that the intervention group had respondents with multiparity (maternity >two times) higher disbanded $\mathrm{n}$ gran with respondents primiparas that as many as $63 \%$. Whereas in the control group, respondents with primiparous were fewer than respondents with multiparity, namely as much as $44 \%$.

Table 2. Sample characteristics (Continous data)

\begin{tabular}{lcccc}
\hline Variables & Mean & SD & Min. & Max. \\
\hline Early Mobilization & & & & \\
Intervention & 0.84 & 0.37 & 0.50 & 1.75 \\
Control & 1.26 & 0.58 & 0.50 & 2.00 \\
Uterine Fundus Height (6 hours) & & & & \\
Intervention & 13.43 & 1.95 & 9.00 & 16.90 \\
Control & 12.87 & 1.71 & 9.50 & 15.00 \\
Early Initiation of Breastfeeding & & & & \\
Intervention & 16.44 & 6.84 & 1 & 25 \\
\hline Control & 16.38 & 5.67 & 7 & 25 \\
\hline
\end{tabular}

Based on table 2, it was explained that in the early mobilization variable, the intervention group has higher than the control group (Mean=1.26; $\mathrm{SD}=0.58)$. The uterine fundus height variables explained that the intervention group has higher uterine fundus height than the control group (Mean=13.43; $\mathrm{SD}=1.95)$. The early initiation of breastfeeding variables explained that, the intervention group has length more than the control group (Mean= 16.38; $\mathrm{SD}=6.84)$.

\section{Bivariate Analysis}

In this study, used the independent t-test to know the effect of age, parity, early mobilization, early initiation of breastfeeding, and pineapple fruit in postpartum mothers on uterine involution in independent midwife practice Bengkulu in 2019. Based on the results of the Shapiro- Wilk normality test (sample size $<50$ respondents), obtained pvalue $>0.05$ and is usually distributed, so that it meets the t-test requirements.

Table 3. Effects of age, parity, early mobilization, early initiation of breastfeeding and provision of pineapple fruit on decreasing height fundal uterus in postpartum mothers

\begin{tabular}{lllll}
\hline Variables & Group & Mean & SD & p \\
\hline Uterine Fundus Height in 3 days (cm) & Intervention & 2.55 & 1.66 & $<0.001$ \\
& Control & 8.39 & 1.48 & \\
Age (Year) & Intervention & 33.19 & 7.57 & 0.057 \\
& Control & 27.56 & 8.45 & \\
Early Mobilization (Hours) & Intervention & 0.84 & 0.37 & 0.022 \\
& Control & 1.26 & 0.58 & \\
Parity (Time) & Intervention & 2.38 & 1.45 & 0.613 \\
& Control & 2.12 & 1.31 & \\
BMI $\left(\mathrm{kg} / \mathrm{m}^{2}\right)$ & Intervention & 16.44 & 6.84 & 0.978 \\
& Control & 16.38 & 5.67 & \\
\hline
\end{tabular}


Table 3 showed that the uterine fundal height variable on 3 days, the intervention group experienced a decrease in height fundal uterus faster than the control group (Mean= 2.55; $\mathrm{SD}=1.66)$ and the control group (Mean $=8.39 ; \mathrm{SD}=1.48)$ and $\mathrm{p}$ $<0.001$. On the variables, age, parity, and early initiation of breastfeeding did not affect the decrease in height fundal uterine, in the SD intervention group $(\mathrm{p}=0.057 ; \mathrm{p}=$ $0.613 ; p=0.978)$. The early mobilization variable, the intervention group did early mobilization faster when compared to the control group (Mean $=0.84 ; \mathrm{SD}=0.37)$ and the control group $(\mathrm{Mean}=1.26 ; \mathrm{SD}=0.58)$, with $\mathrm{p}=0.022$.

\section{DISCUSSION}

Statistic test results in Table 3 explain that there was variable pineapple, $p<0.001$, which means that there is the influence of pineapple juice to the decline of early initiation of breastfeeding on independent midwife practice postpartum mothers in the city of Bengkulu. For mothers who consumed pineapple fruit, the results showed a decrease in independent midwife practice of $5.8437 \mathrm{~cm}$ faster than the group that did not consume pineapple fruit. Pineapple fruit was given to the intervention group in pineapple juice, which is obtained from 450 grams of fresh pineapple fruit. Pineapple fruit is provided every day for three days. A decrease in independent midwife practice can occur because pineapple contains the enzyme bromelain suitable for postpartum mothers (Masri et al., 2014 ; Priya et al., 2017). The enzyme bromelain contained in pineapple serves to stimulate prostaglandin expenditure that PGF2 $\alpha$ derived from the endometrium, causing myometrium to contract action, subsequent smooth muscle found in the uterus will contract (Muzzaman, 2009; Katno et al., 2010; Silaban et al., 2016). A study suggests that the enzyme bromelain at a dose of $3.66 \mathrm{mg} / \mathrm{ml}$, can cause the enzyme bromelain to be stable in the form of stomach acid after 4 hours to react and at a dose of 2:44 mg Remained in the blood (Pavan et al., 2012).

Bromelain enzyme is a proteolytic enzyme or protease, an enzyme that catalyzes the breakdown of protein into amino acids by building blocks through hydrolysis reactions (Maryam, 2009; Purwaningsih, 2017; Warochmah, 2017). Besides, this enzyme can also increase the hydrolytic activity found in the collagen connective tissue (Bilek et al., 2015). Collagen is a connective tissue in the uterus/ uterine support structures that indicate the rapid growth of the endometrial gland. Decreased collagen can cause the elasticity in the uterine muscles to reduce and make the muscles stiff. This decrease in collagen usually occurs as a result of increasing age and a bad lifestyle. Collagen type III is a type of collagen found in the uterus (Bilek et al., 2015). The collagen hydrolysis process will form gelatin. Gelatin is a protein derivative from collagen that can create a thin, healthy, and elastic layer, and has high digestibility (Bilek et al., 2015). So it can be concluded that by hydrolyzing collagen, it can cause the uterine muscles to become flexible, soft, and the connective tissue loosens. The tissue in the uterine muscle will be destroyed and absorbed by the blood, so that blood circulation in the uterus will decrease and facilitate the process of uterine involution (decrease in independent midwife practice) (Sherwood, 2018). A good uterine involution process is characterized by decreased independent midwife practice and smooth discharge of lochea. Involution of the uterus that occurs by autolysis, where bromelain catalyzes the protein in the uterus, then the protein breaks, which is indicated by the uterine muscle tissue that will be destroyed and 
absorbed by blood and then excreted by the kidneys, causing the postpartum mother to urinate frequently (Prawirohardjo, 2008).

Some studies report about the effect pineapples for reduction uterine fundal height for postpartum mothers, in the study by Harianja et al. (2017) using ripe pineapple fruit as much as 250 grams of juice, to 200cc with an intensity of giving once a day for seven days; the result was a decrease in the average height of the uterine fundus by $8,15 \mathrm{~cm}$ for seven days. The study by Apsari et al. (2016) using female mice, then given the extract of young and old pineapple fruit, the results showed that pineapple extract with a concentration of $0.6 \%$ could increase uterine contractions by 0.944 times faster than aged pineapple extract.

In this study, in the intervention group given pineapple juice obtained from 450 grams of fresh pineapple fruit is proven to accelerate the process of decreasing $3^{-}$ day uterine fundal height in postpartum mothers by $5.8437 \mathrm{~cm}$ compared to the control group. It is because the bromelain contained in pineapple helps the process of collagen hydrolysis and protein catalysis, causing the uterine muscles to become elastic, soft, strong, have high absorption, and a method of autolysis of the uterus involution occurs. In the control group, respondents experienced a decrease in the uterus according to the theory of ambarwati and wulandari (Ambarwati et al., 2010), which states that immediately after giving birth, the fundal height of the uterus is $2 \mathrm{~cm}$ below the center, 12 hours later, it returns 1 $\mathrm{cm}$ above the center and decreases by approximately $1 \mathrm{~cm}$ every day. On the second day after delivery, the fundal height was $1 \mathrm{~cm}$ below the center. On days $3-4$, the uterine fundal height $2 \mathrm{~cm}$ below the center. On days $5^{-} 7$, the height of the uterine fundus is half central to the symphysis. On day 10, the uterine fundal height was not palpable.

Apart from pineapple fruit, early mobilization can also help accelerate the reduction of height fundal uterus in postpartum mothers at independent midwife practice Bengkulu. Early mobilization is the process of the activity (Susiwati et al., 2016; Apriana et al., 2013). After the operation, it was done lightly over where to sleep up to be down from the bed, walked into the room mandi, and walked out of the room (Paul et al., 2015). It is because by doing early mobilization, it can help the abdominal and pelvic muscles to return to their pre-pregnancy state by contracting and contracting. The uterus is contracting, and rectifying can cause blood flow to the uterus to be reduced. So that the uterus will experience anemia and the uterine muscle atrophy, resulting in the process of uterine involution.

Based on this study, the provision of pineapple juice and early mobilization are two factors that influence the reduction of independent midwife practice and mobilization can also help the process of uterine involutio, so this factor can be recommended for postpartum mothers.

\section{AUTHOR CONTRIBUTION}

Jesica Mulyadi was the main researcher who collected data, formulated data, and designed research. Mariati gave suggestions for discussion of research and Rachmawati conducted questionnaire reliability tests. Lusi Andriani checked the data and analyzed the data.

\section{CONFLICT OF INTEREST}

There was no conflict of interest in this study.

FUNDING AND SPONSORSHIP 
Mulyadi et al./ Pineapple Juice for Uterine Fundal Height Reduction

This study used the main researcher funds.

\section{ACKNOWLEDGEMENT}

The author would like to thank the postpartum mothers and midwives in the district Gading Cempaka, Ratu Agung, and Singaran Pati who contributed and are willing to be the study subjects in this research.

\section{REFERENCE}

Ambarwati ER, Wulandari, D (2010). Postpartum midwifery care. Yogyakarta: Nuha Medika.

Apriana R, Wulandari P, Aristika NP (2016). Pengaruh mobilisasi dini terhadap penurunan tinggi fundus uteri pada ibu postpartum spontan di RSUD Tugurejo Semarang. MUSWIL IPEMI Jateng. 138-144. https://ppnijateng.org/wp-content/uploads/2016/11/PROSIDING-MUSWIL-II-IPEMIJATENG_MAGELANG-17-SEPTEMBER-2016.147-153.pdf.

Apsari DD, Purwatiningrum DA, Soeharto S (2016). Perbandingan efek pemberian ekstrak buah nanas muda dan ekstrak buah nanas tua terhadap kontraktilitas uterus terpisah marmut (Cavia porcellus) (Comparison of the effects of giving young pineapple extract and old pineapple extract against contractility of marmot (Cavia porcellus). Majalah Kesehatan Faksultas Kedokteran, Universitas Brawijaya. 1(2): 117-124. https://majalahfk.ub.ac.id/index.php/mkfkub/article/view/32/3 o.

Bateman BT, Berman MF, Riley LE, Leffert LR (2010). The epidemiology of postpartum hemorrhage in a large, nationwide sample of deliveries. Anesth and Analg. 110(5): 1368-1373. https://doi.org/10.1213/ane.obo13e3 $181 \mathrm{~d} 74898$.
Bilek SE, Bayram SK (2015). Fruit juice drink production containing hydrolyzed collagen. J Functional Foods. (14): 562-569. doi: 10.1016/j.jff.2015.02.024.

BPS et al. (2013). Indonesian demographic and health survey 2012. IDHS: 16 . doi: 10.1111/j.1471-0528.2007.01580.x.

Harianja WY, Setiani O, Umaroh U, Widyawati MN, Mashoedi ID, Pujiastuti SE (2017). The impact of pineapple (Ananas Comosus (L.) Merr.) juice on fundal height in primigravida mothers during postpartum period. Belitung Nursing Journal. 3(2): 134-141. https://doi.org/10.33546/bnj.76.

Ho M, Li TC, Su SY (2011). The association between traditional Chinese dietary and herbal therapies and uterine involution in postpartum women. Evid Based Complement Alternat Med. 2011: 918291. https://doi.org/10.1155/2011/918291.

Katno, Pramono S (2010). Level of benefits and safety of medicinal plants and traditional medicines.

Maryam S (2009). Ekstrak enzim bromelain dari buah nanas (ananas sativus shuclt) dan pemanfaatannya pada isolasi DNA. Fakultas Matematika dan Ilmu pengetahuan Alam Universitas Negeri Semarang. 1-32.

Masri M, Musa M (2014). Isolasi dan pengukuran aktivitas enzim bromelin dari ekstrak kasar bonggol nanas (Ananas comosus) pada variasi suhu dan pH. Biogenesis: Jurnal Ilmiah Biologi. 2(2): 119-125. doi: 10.24252/bio.v2i2.478.

Moedjiarto S (2011). Post Partum di RB medika utama wonokupang Balongbendo sidoarjo tahun 2009. Hospital Majapahit. 3(1) : 87-103.

Muzzaman MAK (2009). Effect of young 
Mulyadi et al./ Pineapple Juice for Uterine Fundal Height Reduction

pineapple extract (Ananas Comosus L. Merr) on the contractility of the uterine plain muscle separated from female marmots (Cavia Porcellus).

Paul PA, Williams B (2015). Brunner and suddarth's canadian textbook of medical-surgical nursing in surgery. 3rd edn. Canada: Wolters Kluwer.

Pavan R, Jain S, Shraddha, Kumar A (2012). Properties and Therapeutic application of Bromelain: A Review. Biotechnol Res Int. 1-6. https://dx.doi.org/10.1155\%2F2012\%2F976203.

Prawirohardjo S (2008). Midwifery. 4th edn. Edited by S. Prawirohardjo et al. Jakarta: PT Bina Pustaka Sarwono Prawirohardjo.

Priya SP, et al. (2017). Immobilization and kinetic studies of bromelain: a plant cysteine protoase from pineapple (Ananas Comosus) Plant Parts. Int J Med Health Sci. 6(1): 27-33. https://www.cabdirect.org/cabdirect/abstr act/20173140127.

Purwaningsih I (2017). Potensi enzim bromelin sari buah nanas (ananas comosus l.) dalam meningkatkan kadar protein pada tahu. Jurnal Teknologi Laboratorium. 6(1): 39. doi: 10.29238/teknolabjournal.v6i1.86.

Sherwood C (2018). Collagen Function. Available at: https://healthfully.com/collagen-functions-4176583.html.

Silaban I, Rahmanisa S (2016). Pengaruh enzim bromelain buah nanas (Ananas comosus $L$.) terhadap awal kehamilan (The effect of bromelin in pineapple (Ananas comosus L.) on early pregnancy. Majority, 5(4): 80-85. https://juke.kedokteran.unila.ac.id/index.p $\mathrm{hp} /$ majority/article/view/889.

Susiwati, Wagiyo, Elisa (2016). Pengaruh Pijat Oksitosin dan Mobilisasi Dini Terhadap Penurunan Tinggi Fundus Uterus pada Ibu Post Partum di BPM Demak. Jurnal Ilmu Keperawatan dan Kebidanan. 1-9.

Warochmah M (2017). Amobilisasi enzim bromelin dari buah nanas (Ananas Comosus L. Merr.) menggunakan matriks kitosan matriks kitosan untuk pengurangan untuk pengurangan kandungan protein pada air limbah kandungan protein pada air limbah pabrik tahu. Institut Teknologi Sepuluh November. doi: 10.1017/CBO9781107415324.004. 